\title{
Synthesis of $\mathrm{CaO}-\mathrm{SiO}_{2}$ Compounds Using Materials Extracted from Industrial Wastes
}

\author{
Nobuaki Yamaguchi'1, Yoshiko Masuda², Yoshishige Yamada², Hideaki Narusawa', \\ Cho Han-Cheol11, Yukimichi Tamaki3', Takashi Miyazaki'1 \\ ${ }^{1}$ Department of Conservative Dentistry, Division of Biomaterials \& Engineering, Showa University School of \\ Dentistry, Tokyo, Japan \\ ${ }^{2}$ Department of Conservative Dentistry, Division of Endodontology, Showa University School of Dentistry, \\ Tokyo, Japan \\ ${ }^{3}$ Department of Dental Materials Science, Asahi University School of Dentistry, \\ Gifu, Japan \\ Email: ${ }^{*}$ tamaki@dent.asahi-u.ac.jp
}

Received 7 October 2014; revised 10 November 2014; accepted 10 December 2014

Copyright (C) 2015 by authors and Scientific Research Publishing Inc.

This work is licensed under the Creative Commons Attribution International License (CC BY). http://creativecommons.org/licenses/by/4.0/

(c) (i)

Open Access

\begin{abstract}
Mineral trioxide aggregate (MTA) cement is an attractive material in endodontic dentistry. The purpose of this study was to produce calcium silicate, which is a major component of MTA, from waste materials. A dental alginate impression gel and used chalks were selected and mixed in a suitable ratio (Code: EXP). As a control, $\mathrm{CaCO}_{3}$ and a commercial diatomite were used (Code: $\mathrm{CON}$ ). Each powder was heated to $850^{\circ} \mathrm{C}$ and $1000^{\circ} \mathrm{C}$, and then kneaded with water. TG-DTA, compressive tests, SEM observations, elemental mapping analyses, and XRD analyses were performed. TG-DTA indicated that weight reduction of $\mathrm{CaCO}_{3}$ started at $600^{\circ} \mathrm{C}$, and it completely decomposed on heating at $850^{\circ} \mathrm{C}$. The strength was affected by the temperature. After heating, $\mathrm{CaCO}_{3}$ was transformed into $\mathrm{CaO}$ and/or $\mathrm{Ca}_{2} \mathrm{SiO}_{4}$, and $\mathrm{Ca}(\mathrm{OH})_{2}$ was formed by mixing with water. There were no differences between EXP and CON. These data suggested that recycled wastes might be promising MTA sources.
\end{abstract}

\section{Keywords}

Recycling, Calcium Silicate, Diatomite, Alginate Impression Material, Calcium Hydroxide

\section{Introduction}

Most used materials generally become wastes, and dental materials such as waxes, impression materials, gyp-

"Corresponding author.

How to cite this paper: Yamaguchi, N., Masuda, Y., Yamada, Y., Narusawa, H., Han-Cheol, C., Tamaki, Y. and Miyazaki, T. (2015) Synthesis of $\mathrm{CaO}-\mathrm{SiO}_{2}$ Compounds Using Materials Extracted from Industrial Wastes. Open Journal of Inorganic Non-Metallic Materials, 5, 1-10. http://dx.doi.org/10.4236/ojinm.2015.51001 
sum, investment materials, and acrylic resins are also handled as industrial wastes; however, they may also contain some reusable materials and/or recyclable waste [1]-[3]. In particular, inorganic substances such as oxides, nitrides, hydroxides, and sulfides are valuable resources. Recently, some oxide materials have been shown to be promising for metal-free restoration because they have sufficient strength, no flammability, high stiffness, a natural tooth-color, and excellent bio-inertness [4]-[6]. Such materials are used in clinical restoration as composites with monomers. Because of the aesthetic outcome and their safety for use in humans, these ceramics are valuable in dentistry.

Mineral trioxide aggregate (MTA) cement is an attractive material in endodontic dentistry, especially for teeth with severe and/or long-term root canal treatment [7]-[10]. Root canal treatment usually involves delicate work because of the limited view and area. As a result, the possibility of accidents increases, and, unfortunately, this may lead to tooth extraction. It has been reported that MTA consists mainly of various calcium compounds such as calcium silicates $\left(\mathrm{Ca}_{3} \mathrm{SiO}_{5}, \mathrm{Ca}_{2} \mathrm{SiO}_{4}, \mathrm{CaSiO}_{3}\right)$, calcium aluminate $\left(\mathrm{CaAl}_{2} \mathrm{O}_{4}\right)$, and calcium sulfate $\left(\mathrm{CaSO}_{4} \cdot 2 \mathrm{H}_{2} \mathrm{O}\right)$ [9] [11]. Calcium silicates in particular have been reported to have excellent antibacterial, hard tissue regeneration, and bone conductivity properties [12] [13]. Specifically, dicalcium silicate [11] or tricalcium silicate [13][15] produces calcium hydroxide in chemical reactions with water, and hardens MTA [9]. Excellent properties are obtained as a result of the strong alkalinity of calcium hydroxide [11] [16] [17]. Calcium silicate plays a pivotal role in these characteristics and predominates in MTA [9]-[11]. However, as is well known, MTA is more expensive than other dental products for root canal treatment.

The industrial syntheses of calcium silicates are represented as follows [9]:

$$
\mathrm{CaO}+\mathrm{SiO}_{2} \rightarrow \mathrm{CaSiO}_{3}, \quad 2 \mathrm{CaO}+\mathrm{SiO}_{2} \rightarrow \mathrm{Ca}_{2} \mathrm{SiO}_{4}, \quad 3 \mathrm{CaO}+\mathrm{SiO}_{2} \rightarrow \mathrm{Ca}_{3} \mathrm{SiO}_{5}
$$

Calcium silicate is produced by the reaction between $\mathrm{SiO}_{2}$ and $\mathrm{CaO}$. In dentistry, $\mathrm{SiO}_{2}$ is a very popular compound and is frequently used not only as a refractory in dental investment materials (quartz or cristobalite), but also as a component of dental materials such as porcelain powder, model resins for veneering crowns, filling resin composite materials, and glass ionomer cements. $\mathrm{CaO}$ is not used as a raw material in dentistry; however, several dental products contain $\mathrm{CaO}$. Gypsum is a model $\mathrm{CaO}$-containing compound. $\mathrm{CaO}$ can be derived from such compounds using various procedures. For instance, when a molten metal at above $1000^{\circ} \mathrm{C}$ comes into contact with a gypsum-bonded material, $\mathrm{CaO}$ is produced by decomposition of the gypsum.

The purpose of this study was to investigate the possibility of obtaining MTA-like cement products from waste materials. To do this, it is necessary to produce calcium silicate from these wastes. First, we investigated the synthesis of calcium silicate from recycled waste materials, and then generated calcium hydroxide by kneading with water. Generally, commercial alginate impression products contain more than 60 wt $\%$ diatomite [18]. Diatomite consists of diatomaceous fossils, originally algae, and its chemical formula is $\mathrm{SiO}_{2}$. It is $\mathrm{known}$ that $\mathrm{SiO}_{2}$ is allotropic and is divided into quartz, tridymite, cristobalite, and amorphous silica glass, with different crystal structures. However, quartz and cristobalite have poor reactivities with other compounds because of their stabilities at high temperature. Diatomite has a porous structure and is relatively reactive at low temperature.

\section{Materials and Methods}

\subsection{Powder Preparation}

To extract silicon dioxide, a commercial alginate impression product (Algiace Z, DENTSPLY International Inc., Tokyo, Japan), which includes 70 wt\% diatomite $\left(\mathrm{SiO}_{2}\right)$, was selected. On the assumption that the taking of impressions from patients had been completed, the powder was mixed with water and then gelled. The obtained gel was heated in a ceramic dish in an electric furnace at $800^{\circ} \mathrm{C}$. The residual pieces obtained by firing were milled using a pestle and a mortar, and then retrieved. This procedure is shown in Figure 1.

Although it is not impossible to extract $\mathrm{CaO}$ from gypsum products, as described above, an electric furnace with a high-power source is needed, for firing at $1200^{\circ} \mathrm{C}$ [19]. We therefore investigated another compound, which easily generates $\mathrm{CaO}$. Chalk is a calcium-based compound that is used routinely in elementary schools. Chalk consists of calcium carbonate, and used chalk usually becomes waste. Also, the decomposition temperature of $\mathrm{CaCO}_{3}$ is lower than that of gypsum [20]. To synthesize calcium silicate, both an alginate impression gel and chalk powder were prepared.

Used chalk (Dustless Chalk, Nihon Rikagaku Industry Co., Ltd., Kawasaki, Japan) was similarly pulverized 


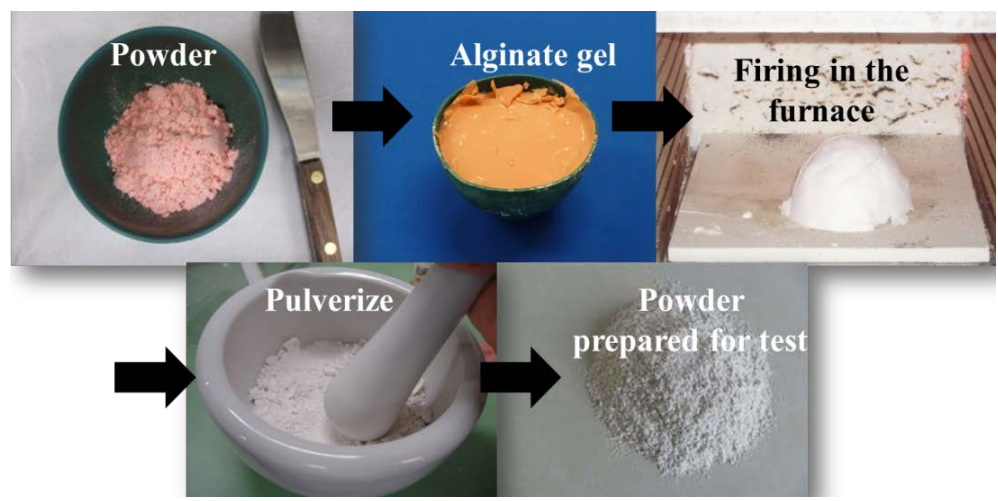

Figure 1. Preparation of diatomite extracted from alginate impression gel.

and retrieved.

Reagent-grade calcium carbonate (Wako Pure Chemical Industries, Ltd., Osaka, Japan) and a commercial diatomite (Wakkanai Green Factory Co., Ltd., Wakkanai, Japan) were used as references to check the validity of the experimental results.

\subsection{Synthesis of Calcium Silicate}

The diatomite/ $\mathrm{CaCO}_{3}$ ratio was calculated based on molecular weights, using the following chemical formula:

$$
2 \mathrm{CaCO}_{3}+\mathrm{SiO}_{2} \rightarrow \mathrm{Ca}_{2} \mathrm{SiO}_{4}+2 \mathrm{CO}_{2}
$$

Calcium carbonate ( $3 \mathrm{~g})$ and diatomite $(10 \mathrm{~g})$ were used to produce $\mathrm{Ca}_{2} \mathrm{SiO}_{4}$.

$\mathrm{CaCO}_{3}$ was blended with diatomite in the above quantities, and the mixture was placed in a heat-resistant dish and uniformly kneaded with distilled water at a water $(\mathrm{mL}) /$ powder $(\mathrm{g})$ ratio (W/P) of 0.4 for $30 \mathrm{~s}$. The mixture consisting of both alginate impression material and dustless chalk was the experimental sample (Code: EXP). After sufficient drying, the mixture was heated at $10^{\circ} \mathrm{C} / \mathrm{min}$ in an automatic electric furnace (KDF-009, Yoshida Co., Ltd., Tokyo, Japan). The limit of the heating temperature was $850^{\circ} \mathrm{C}$ or $1000^{\circ} \mathrm{C}$. As a control (Code: CON), a mixture consisting of commercial ingredients (diatomite and $\mathrm{CaCO}_{3}$ ) was prepared for comparison with EXP. All the materials prepared for the experiments are listed in Table 1.

\subsection{Thermal Analysis}

In this study, thermo-decomposition of calcium carbonate was required for the synthesis of $\mathrm{Ca}_{2} \mathrm{SiO}_{4}$. Moreover, the calcium oxide formed during heating needed to react with silicon dioxide. The thermal behaviors of two $\mathrm{CaCO}_{3}$ powders and two mixtures (EXP and $\mathrm{CON}$ ) were therefore measured using thermo-mechanical analysis equipment (Thermo Plus TMA 8310, Rigaku Co., Ltd., Tokyo, Japan). Thermogravimetric/differential thermal analysis (TG-DTA) was performed on each of the prepared powders. Around $30 \mathrm{mg}$ of sample were placed in a platinum pan, heated up to $1500^{\circ} \mathrm{C}$ at $10^{\circ} \mathrm{C} / \mathrm{min}$, and then heat-soaked for $10 \mathrm{~min}$. Changes in the weights of the samples were monitored along with the exothermic or endothermic nature of the reaction.

\subsection{X-Ray Diffraction (XRD) Analysis}

The compositions of the powders after heating were evaluated using XRD (XRD 6100, Shimadzu Corp., Kyoto, Japan). Sample powders were placed in the glass holder and analyzed using $\mathrm{Cu}-\mathrm{K} \alpha$ radiation, at $40 \mathrm{kV}$ and 30 $\mathrm{mA}$, with a scanning speed of $2^{\circ} / \mathrm{min}$ and a scanning range of $10^{\circ}-70^{\circ}$. The XRD analyses were performed on the following samples:

1) four kinds of powders prior to mixing $\left(\mathrm{SiO}_{2}\right.$ : fired alginate gel and commercial diatomite; $\mathrm{CaCO}_{3}$ : chalk and the reagent);

2) EXP and CON blended with water;

3) EXP and CON fired at $850^{\circ} \mathrm{C}$ and $1000^{\circ} \mathrm{C}$;

4) $\mathrm{EXP}$ and $\mathrm{CON}$ blended with water after firing at $850^{\circ} \mathrm{C}$ and $1000^{\circ} \mathrm{C}$. 
Table 1. Materials tested in this study.

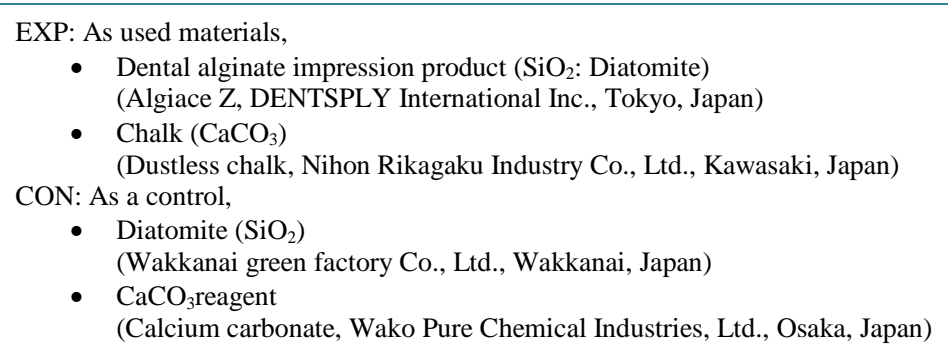

\subsection{Scanning Electron Microscopy (SEM) Observations}

The fired alginate gel and commercial diatomite were observed using SEM (SEM 8000, Hitachi Co., Ltd., Tokyo, Japan) and their morphologies were compared. In addition, SEM observations were performed for EXP after firing at $850^{\circ} \mathrm{C}$ and $1000^{\circ} \mathrm{C}$. Prior to placing in the sample holder, specimens were coated with gold.

\subsection{Elemental Mapping Analyses}

Using the same equipment as for the SEM observations, elemental mapping analysis was carried out for the fired alginate impression material to identify included $\mathrm{SiO}_{2}$. The elements mapped were silicon and calcium. To estimate the elemental distribution and/or morphological changes after firing at high temperature, the fired EXP was also examined.

\subsection{Compressive Strength}

The green compressive strengths of EXP and CON (ø $6 \mathrm{~mm}$, height $12 \mathrm{~mm}$ ) after mixing for $24 \mathrm{~h}$ were measured using a universal testing machine (Instron MD-1125, Instron Japan Co., Ltd., Kawasaki, Japan), with a cross-head speed of $1.0 \mathrm{~mm} / \mathrm{min}$.

The lumps obtained after firing at $850^{\circ} \mathrm{C}$ and $1000^{\circ} \mathrm{C}$ were milled. The obtained powders were kneaded with distilled water at a water/powder ratio of 0.5 on a glass plate. Five specimens were prepared for each experiment and the average value was calculated. The obtained data were statistically evaluated by two-way analysis of variance at a significance level of $\alpha=0.05$.

\section{Results}

The thermal analysis results are shown in Figure 2 and Figure 3. There were no clear differences between reagent $\mathrm{CaCO}_{3}$ in Figure 2 and EXP, shown in Figure 3. In both TG-DTA curves, a large endothermic peak was observed at around $600^{\circ} \mathrm{C}$, and then the sample mass started to decrease abruptly. This decrease continued until nearly $800^{\circ} \mathrm{C}$.

In contrast, there were obvious differences between EXP and CON. Although the endothermic reaction with the decomposition of $\mathrm{CaCO}_{3}$ was almost the same, a sharp peak at around $100^{\circ} \mathrm{C}$ was clearly observed in the CON curve.

Figures 4-7 show the results of the XRD analysis. XRD patterns of the four powders prepared for the experiments are shown in Figure 4. The peaks of chalk and calcium carbonate were completely in agreement. Diatomite was the dominant peak in both cases; however, the dental waste had a calcium sulfate peak. A weak quartz peak was detected from the commercial diatomite. The peaks of EXP and CON kneaded with distilled water are shown in Figure 5. These consisted of diatomite and $\mathrm{CaCO}_{3}$, and we confirmed that new compounds formed by reaction with water appeared. After firing at $850^{\circ} \mathrm{C}, \mathrm{EXP}$ and $\mathrm{CON}$ had strong $\mathrm{CaO}$ peaks originating from $\mathrm{CaCO}_{3}$, residual $\mathrm{CaCO}_{3}$, and a weak diatomite peak, as shown in Figure 6. However, $\mathrm{Ca}_{2} \mathrm{SiO}_{4}$ was not formed. In contrast, peaks from $\mathrm{Ca}_{2} \mathrm{SiO}_{4}$ were detected at $31^{\circ}-32^{\circ}$ in EXP and CON after firing at $1000^{\circ} \mathrm{C}$. The peaks of the samples fired at $1000^{\circ} \mathrm{C}$ were slightly broader than those in the patterns of the samples fired at $850^{\circ} \mathrm{C}$, When powders fired at $850^{\circ} \mathrm{C}$ were kneaded with water, strong peaks for calcium hydroxide $\left[\mathrm{Ca}(\mathrm{OH})_{2}\right]$ were identified at $18^{\circ}$ and $34^{\circ}$. In contrast, the powders fired at $1000^{\circ} \mathrm{C}$ showed weaker peaks from $\mathrm{Ca}(\mathrm{OH})_{2}$ (Figure 7). 


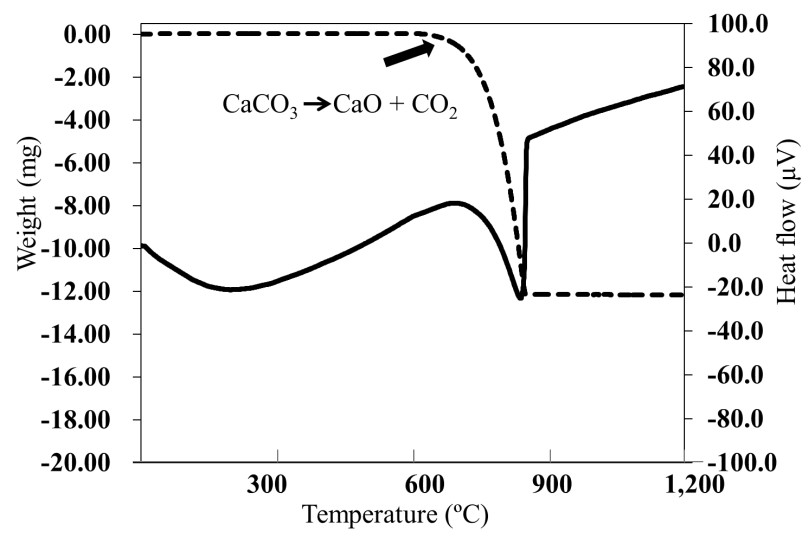

Figure 2. TG-DTA curve for calcium carbonate.

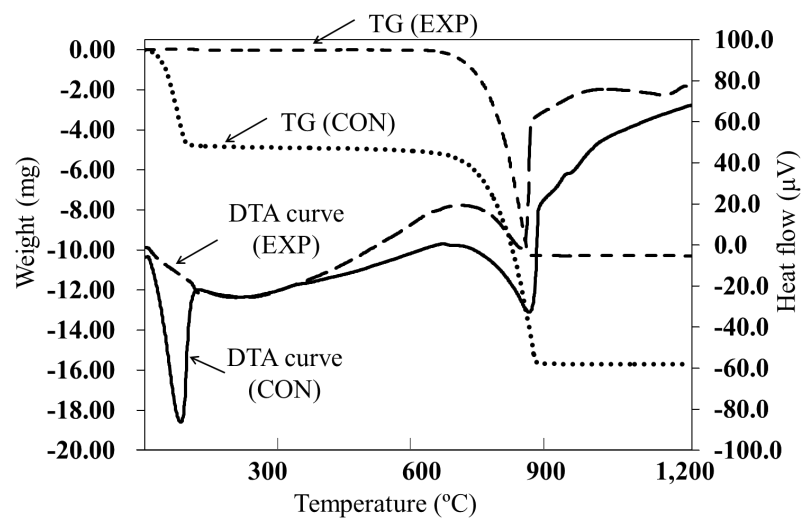

Figure 3. TG-DTA curves for EXP and CON.

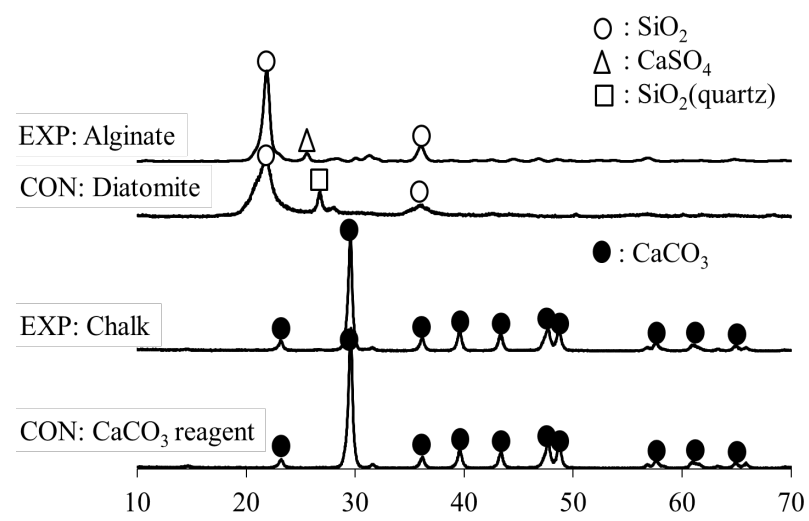

Figure 4. XRD analyses of four materials tested in this study.

SEM images of the diatomites and fired EXP samples are shown in Figure 8. A peculiar diatomite crystal structure was distinctly observed for the fired alginate gel at $850^{\circ} \mathrm{C}$. There were numerous ordered spaces. In contrast, the structure of the commercial diatomite presented a common grain shape, and there were no characteristic patterns like that from the alginate gel. The crystal shape of the diatomite in EXP fired at $850^{\circ} \mathrm{C}$ was retained. Partially fused diatomite and $\mathrm{CaCO}_{3}$ was found for the EXP fired at $1000^{\circ} \mathrm{C}$, indicated by the black arrow in the SEM image in Figure 8.

An elemental map of $\mathrm{Si}$ and $\mathrm{Ca}$ is shown in Figure 9. Silicon existed densely on the diatomite, with a unique structure, and was separate from Ca. In the case of the sample fired at $1000^{\circ} \mathrm{C}$, the diatomite was fused with $\mathrm{CaO}$ and uniform. 


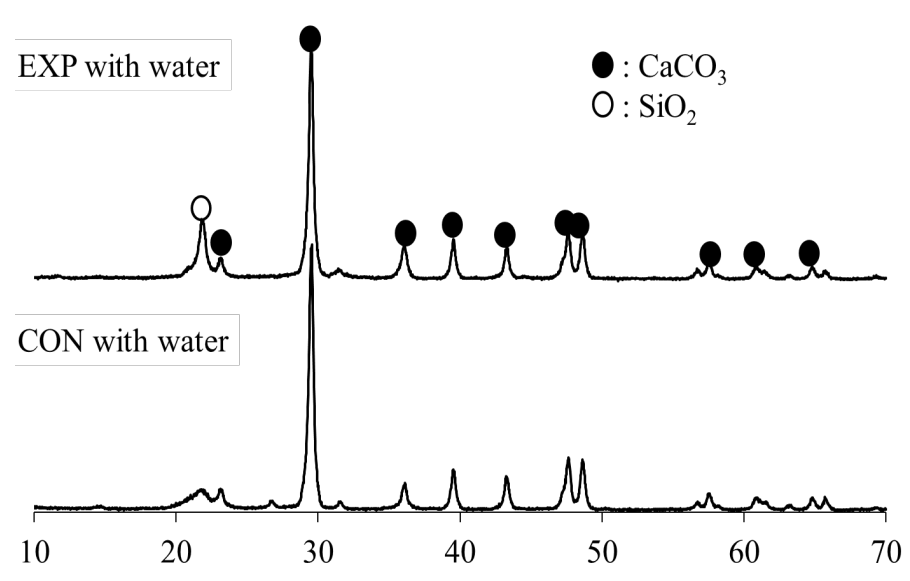

Figure 5. XRD analyses of EXP and CON after kneading with water prior to firing.

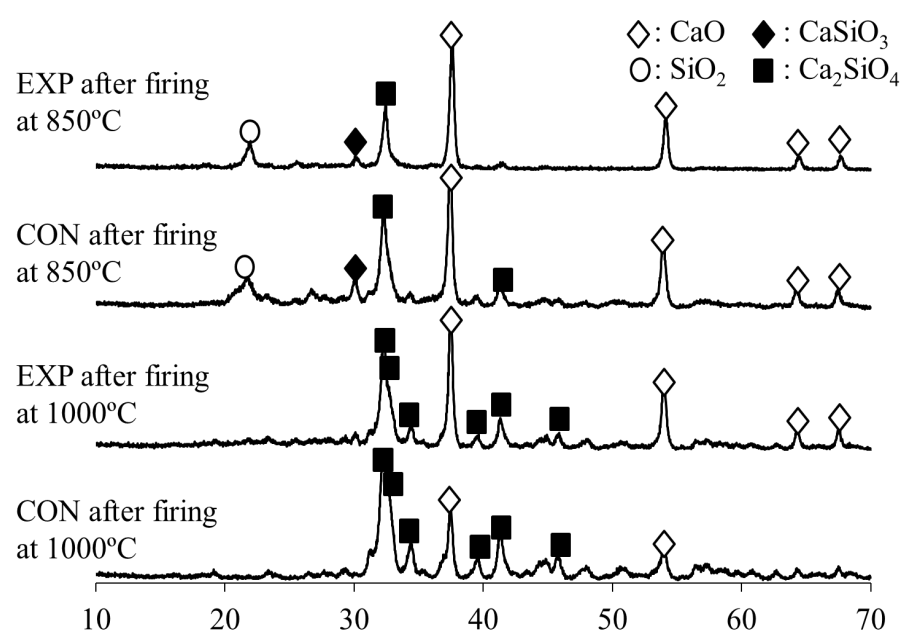

Figure 6. XRD analyses of EXP and CON after firing at $850^{\circ} \mathrm{C}$ and $1000^{\circ} \mathrm{C}$.

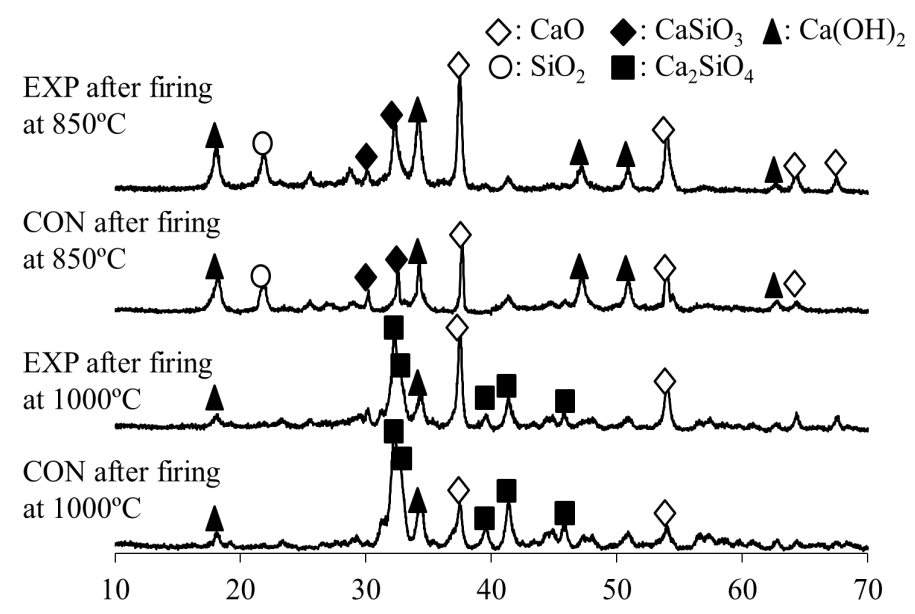

Figure 7. XRD analyses of EXP and CON kneaded with water after firing at $850^{\circ} \mathrm{C}$ and $1000^{\circ} \mathrm{C}$. 

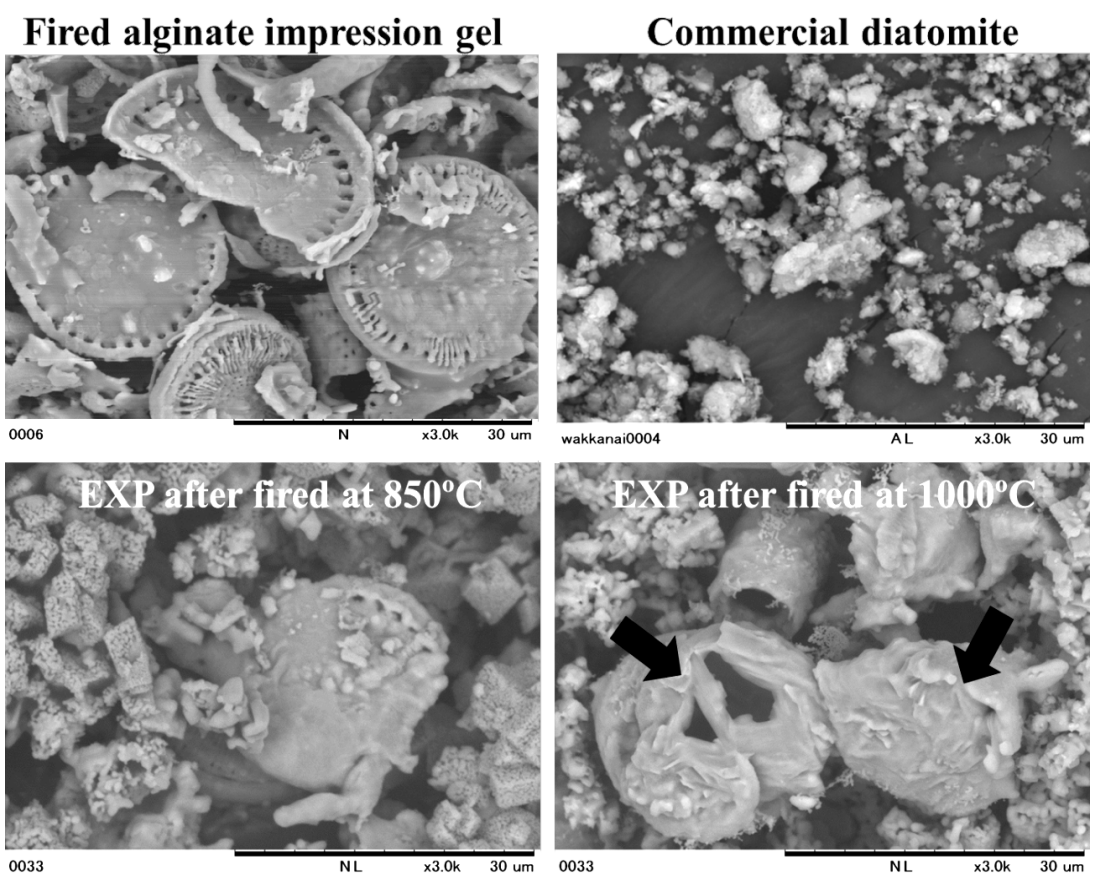

Figure 8. SEM images: upper right: commercial diatomite, upper left: diatomite from alginate gel; lower right: EXP fired at $1000^{\circ} \mathrm{C}$, lower left: EXP fired at $850^{\circ} \mathrm{C}$.

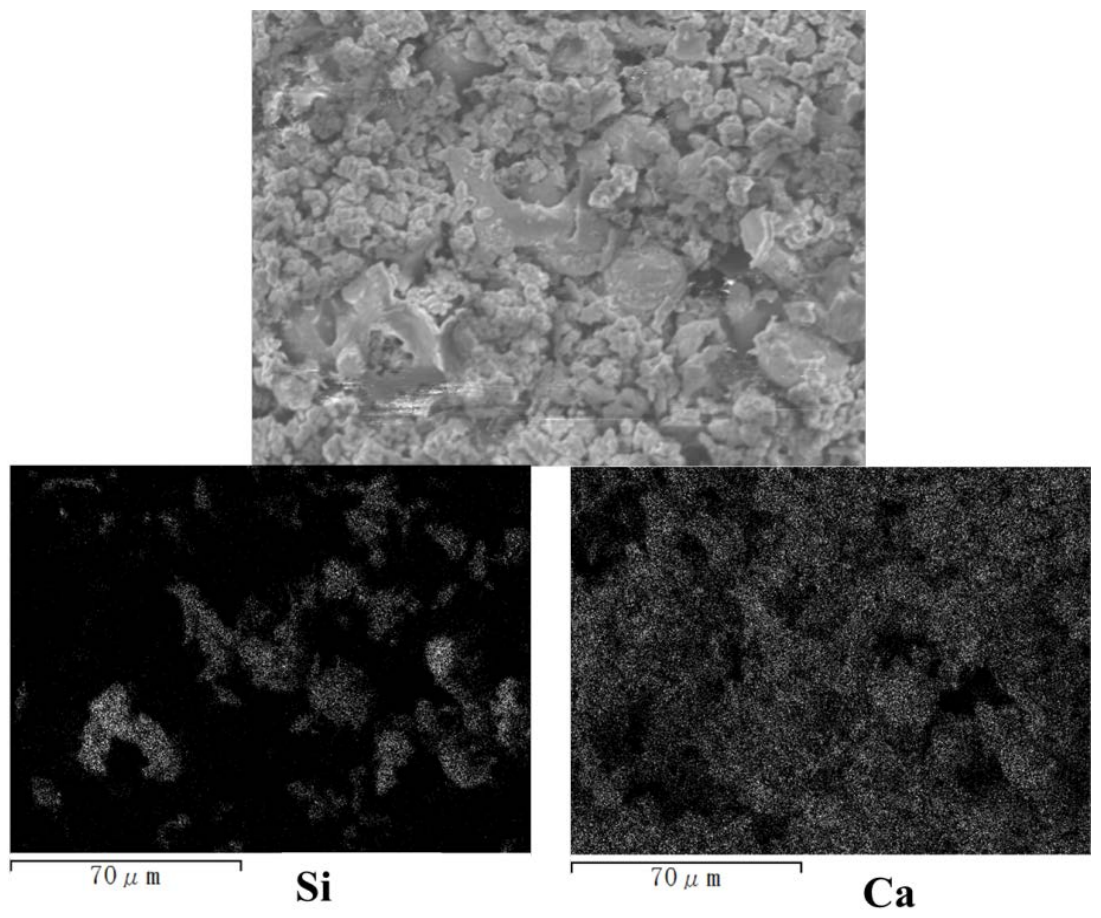

Figure 9. Elemental mapping of EXP fired at $1000^{\circ} \mathrm{C}$. upper: SEM image, lower left: Si distribution, lower right: Ca distribution.

Compressive strength data are shown in Figure 10. The values for EXP and CON were $0.30 \pm 0.05$ and $0.40 \pm$ $0.09(\mathrm{MPa})$, respectively, at $850^{\circ} \mathrm{C}$, and $0.62 \pm 0.23$ and $0.50 \pm 0.08(\mathrm{MPa})$, respectively, at $1000^{\circ} \mathrm{C}$. There was no relationship between strength and the type of powder; however, it was found that the maximum firing temperature significantly affected the strength. 


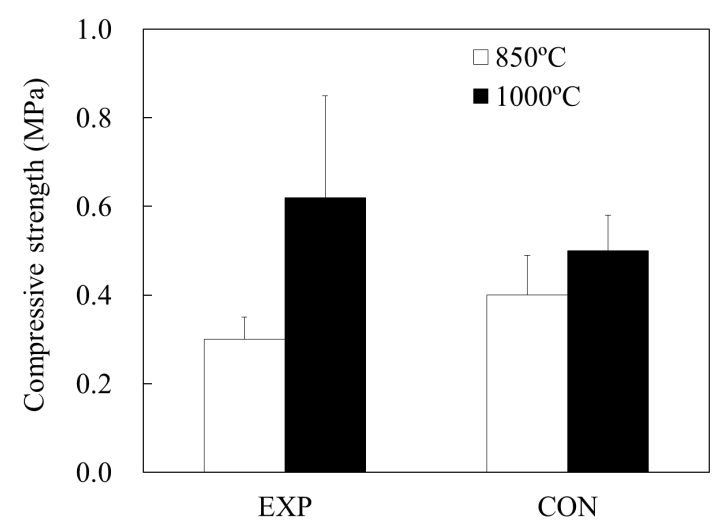

Figure 10. Green compressive strengths of EXP and $\mathrm{CON}$ after firingat $850^{\circ} \mathrm{C}$ and $1000^{\circ} \mathrm{C}$.

\section{Discussion}

It is important to take recycling into consideration because conservation of finite resources has been practiced worldwide since the end of the 20th century. There have been several studies of recycling of dental alloys [21][23], investment materials [1]-[3], and gypsum [24] in dentistry. However, these were concerned with reuse, and recycling in other ways was not considered to any great extent. Our aim was to manufacture new products by extracting ingredients from used products.

To synthesize $\mathrm{Ca}_{2} \mathrm{SiO}_{4}$, which is one of the major components of MTA [7]-[9], we initially explored possible ways of supplying both $\mathrm{SiO}_{2}$ and $\mathrm{CaO}$. Two types of waste, namely used chalk for $\mathrm{CaCO}_{3}$ and alginate impression gel for $\mathrm{SiO}_{2}$ were used.

From the results of thermal analysis, the firing temperature was set at $850^{\circ} \mathrm{C}$ because weight loss from decomposition of $\mathrm{CaCO}_{3}$ was complete below $850^{\circ} \mathrm{C}$. The decomposition of $\mathrm{CaCO}_{3}$ as a result of heat-stress was prominent in the TG-DTA curves, shown in Figure 2 and Figure 3 . The rapid decrease at $100^{\circ} \mathrm{C}$ in the TG-DTA graph of CON was thought to be the result of evaporation of water in the powder. As a result, the total decreases for EXP and CON were different.

Figure 4 showed that the waste materials used in this study had almost the same compositions as reagents and commercial product. However, the shape of the diatomite in the alginate impression material was different from that in the commercial product, as shown in Figure 8. To homogenize the powder prior to firing, each of the mixtures (EXP and CON) was kneaded with water. Since the two different peaks in Figure 4 are both present in Figure 5, it was found that water did not influence the $\mathrm{CaCO}_{3}$ content of the mixture.

Based on TG-DTA results, the following two-step chemical reaction was predicted on firing at $850^{\circ} \mathrm{C}$ :

$$
\mathrm{CaCO}_{3} \rightarrow \mathrm{CaO}+\mathrm{CO}_{2}, \quad 2 \mathrm{CaO}+\mathrm{SiO}_{2} \rightarrow \mathrm{Ca}_{2} \mathrm{SiO}_{4}
$$

The results after firing at $850^{\circ} \mathrm{C}$ showed that $\mathrm{CaCO}_{3}$ had decomposed. However, $\mathrm{Ca}_{2} \mathrm{SiO}_{4}$ peaks were not detected in the XRD pattern. This meant that the firing temperature was not high enough for the second of the above reactions, based on the finding that the $\mathrm{SiO}_{2}$ peak remained after firing. It is reasonable to suppose that a higher temperature than $850^{\circ} \mathrm{C}$ is needed. Under the experimental conditions for the TG-DTA analysis, only a small quantity of EXP or CON was used for the measurements. In order to activate the decomposition of $\mathrm{CaCO}_{3}$, the samples needed to be fired at a temperature above $850^{\circ} \mathrm{C}$.

The notable features of the XRD patterns after firing at $1000^{\circ} \mathrm{C}$ were the disappearance of the $\mathrm{SiO}_{2}$ peak and broadening of the peak at $33^{\circ}$. It is possible that several peaks overlapped. In fact, $\mathrm{Ca}_{2} \mathrm{SiO}_{4}$ has many different crystal types, and these peaks are concentrated at around $32^{\circ}-33^{\circ}$. It was therefore considered that firing at $1000^{\circ} \mathrm{C}$ helps to form $\mathrm{Ca}_{2} \mathrm{SiO}_{4}$. The formation of $\mathrm{Ca}_{2} \mathrm{SiO}_{4}$ can be explained based on the SEM images in Figure 8 and the mapping analysis results.

As a final step, EXP and CON were milled after firing and kneaded with water. The experimental results are shown in Figure 7. The following findings were obtained: $\mathrm{Ca}(\mathrm{OH})_{2}$ was mainly generated from $\mathrm{CaO}$, and this phenomenon was marked at $850^{\circ} \mathrm{C}$, but not at $1000^{\circ} \mathrm{C}$. It is likely that the samples after firing at $850^{\circ} \mathrm{C}$ had insufficient $\mathrm{CaO}$ to form $\mathrm{Ca}_{2} \mathrm{SiO}_{4}$. Initially, we assumed that $\mathrm{Ca}(\mathrm{OH})_{2}$ would also be produced by reaction of wa- 
ter with $\mathrm{Ca}_{2} \mathrm{SiO}_{4}$, based on the following equation:

$$
\mathrm{Ca}_{2} \mathrm{SiO}_{4}+\mathrm{H}_{2} \mathrm{O} \rightarrow \mathrm{Ca}(\mathrm{OH})_{2}+\mathrm{CaSiO}_{3} .
$$

Unexpectedly, it seems that the above reaction does not occur easily. It is therefore reasonable to suppose that the $\mathrm{Ca}(\mathrm{OH})_{2}$ in the sample fired at $1000^{\circ} \mathrm{C}$, shown in Figure 7, was also derived from $\mathrm{CaO}$. It should also be added that the generation of $\mathrm{Ca}_{2} \mathrm{SiO}_{4}$ was time-dependent since we detected strong $\mathrm{Ca}(\mathrm{OH})_{2}$ peaks in the XRD pattern after $24 \mathrm{~h}$.

Another explanation for the formation of $\mathrm{Ca}_{2} \mathrm{SiO}_{4}$ with firing at $1000^{\circ} \mathrm{C}$ is provided by the compressive strength results. As shown in Figure 7, $\mathrm{CaO}$ and/or $\mathrm{Ca}_{2} \mathrm{SiO}_{4}$ were converted to $\mathrm{Ca}(\mathrm{OH})_{2}$ by kneading with water, regardless of the firing temperature. Nevertheless, the difference between the firing temperatures was significant, as shown in Figure 10. It could be inferred from the higher compressive strength obtained from samples fired at $1000^{\circ} \mathrm{C}$ that the formed $\mathrm{Ca}_{2} \mathrm{SiO}_{4}$ plays an important role as a filler.

On the other hand, there are some problems with this study. For instance, the compressive strength is still controversial. Although Portland cement is involved in the hardening of MTA, it was not added to EXP. The green strength value of EXP was therefore inferior to that of MTA previously reported. The hardening mechanism also needs to be improved. In order to improve the mechanical properties and manipulation of EXP, it will be necessary to examine additives and/or reconsider the powder preparation. Additionally, detailed evaluations in cells or organisms have not yet been performed. We will carry out further investigations in the future.

\section{Conclusion}

In summary, these experimental results show that the synthesis of $\mathrm{Ca}_{2} \mathrm{SiO}_{4}$ was possible by the firing at $1000^{\circ} \mathrm{C}$ of a mixture containing both $\mathrm{CaCO}_{3}$ and diatomite. Moreover, the fired mixtures produced $\mathrm{Ca}(\mathrm{OH})_{2}$ on mixing with water. This result was in agreement with a previous report [9]. The EXP sample prepared in this study almost corresponded to the CON sample, which consisted of a reagent and a commercial product, except in the case of the thermal analysis results. In conclusion, it was expected that it would be possible to successfully produce $\mathrm{CaSiO}_{3}$-based compounds with properties like those of MTA by recycling used products.

\section{References}

[1] Aida, Y., Zhang, Z., Yagi, S. and Tamaki, Y. (2009) Experimental Critobalite Investments with Reused Glass Powder as Binder Materials Are Available for Reuse of Casting. Dental Medicine Research, 29, 139-147. http://dx.doi.org/10.7881/dentalmedres.29.139

[2] Zhang, Z., Tamaki, Y., Hotta, Y., Miyazaki, T. (2005) Recycling of Used Commercial Phosphate-Bonded Investments with Additional Mono-Ammonium Phosphate. Dental Materials Journal, 24, 14-18. http://dx.doi.org/10.4012/dmj.24.14

[3] Yagi, S., Zhang, Z., Aida, Y., Hotta, Y., Tamaki, Y. and Miyazaki, T. (2011) Soda-Lime Glass as a Binder in Reusable Experimental Investment for Dental Castings. Dental Materials Journal, 30, 611-615. http://dx.doi.org/10.4012/dmj.2011-040

[4] Vichi, A., Louca, C., Corciolani, G. and Ferrari, M. (2011) Color Related to Ceramic and Zirconia Restorations: A Review. Dental Materials, 27, 97-108. http://dx.doi.org/10.1016/j.dental.2010.10.018

[5] Bottino, M.A., Salazar-Marocho, S.M., Leite, F.P., Vásquez, V.C. and Valandro, L.F. (2009) Flexural Strength of GlassInfiltrated Zirconia/Alumina-Based Ceramics and Feldspathic Veneering Porcelains. Journal of Prosthodontics, 18, 417420. http://dx.doi.org/10.1111/j.1532-849X.2009.00462.X

[6] Miyazaki, T. and Hotta, Y. (2011) CAD/CAM Systems Available for the Fabrication of Crown and Bridge Restorations. Australian Dental Journal, 56, 97-106. http://dx.doi.org/10.1111/j.1834-7819.2010.01300.x

[7] Aeinehchi, M., Eslami, B., Ghanbariha, M. and Saffar, A.S. (2003) Mineral Trioxide Aggregate (MTA) and Calcium Hydroxide as Pulp-Capping Agents in Human Teeth: A Preliminary Report. International Endodontic Journal, 36, 225-231. http://dx.doi.org/10.1046/j.1365-2591.2003.00652.x

[8] Dammaschke, T., Gerth, H.U.V., Zuchner, H. and Schafer, E. (2005) Chemical and Physical Surface and Bulk Material Characterization of White ProRoot MTA and Two Portland Cements. Dental Materials, 21, 731-738. http://dx.doi.org/10.1016/j.dental.2005.01.019

[9] Darvell, B.W. and Wu, R.C.T. (2011) “MTA”-An Hydraulic Silicate Cement: Review Update and Setting Reaction. Dental Materials, 27, 407-422. http://dx.doi.org/10.1016/j.dental.2011.02.001 
[10] Han, L. and Okiji, T. (2011) Uptake of Calcium and Silicon Released from Calcium Silicate-Based Endodontic Materials into Root Canal Dentine. International Endodontic Journal, 44, 1081-1087. http://dx.doi.org/10.1111/j.1365-2591.2011.01924.X

[11] Chiang, T.Y. and Ding, S.J. (2010) Comparative Physicochemical and Biocompatible Properties of Radiopaque Dicalcium Silicate Cement and Mineral Trioxide Aggregate. Journal of Endodontics, 36, 1683-1687. http://dx.doi.org/10.1016/j.joen.2010.07.003

[12] Liu, X., Morra, M., Carpi, A. and Li, B. (2008) Bioactive Calcium Silicate Ceramics and Coatings. Biomedicine \& Pharmacotherapy, 62, 526-529. http://dx.doi.org/10.1016/j.biopha.2008.07.051

[13] Gandolfia, M.G., Ciapettib, G., Taddeic, P., Perutb, F., Tinti, A., Cardosod, M.V., Meerbeek, B.V. and Prati, C. (2010) Apatite Formation on Bioactive Calcium-Silicate Cements for Dentistry Affects Surface Topography and Human Marrow Stromal Cells Proliferation. Dental Materials, 26, 974-992. http://dx.doi.org/10.1016/j.dental.2010.06.002

[14] Liu, W.-N., Chang, J., Zhu, Y.-Q. and Zhang M. (2011) Effect of Tricalcium Aluminate on the Properties of Tricalcium Silicate-Tricalcium Aluminate Mixtures: Setting Time, Mechanical Strength and Biocompatibility. International Endodontic Journal, 44, 41-50. http://dx.doi.org/10.1111/j.1365-2591.2010.01793.x

[15] Camilleri, J. (2011) Characterization and Hydration Kinetics of Tricalcium Silicate Cement for Use a Dental Biomaterial. Dental Materials, 27, 836-844. http://dx.doi.org/10.1016/j.dental.2011.04.010

[16] Marao, H.F., Panzarini, S.R., Aranega, A.M., Sonoda, C.K., Poi, W.R., Esteves, J.C. and Silva, P.I.S. (2012) Periapical Tissue Reactions to Calcium Hydroxide and MTA after External Root Resorption as a Sequera of Delayed Tooth Replantation. Dental Traumatology, 28, 306-313. http://dx.doi.org/10.1111/j.1600-9657.2011.01090.x

[17] Pelisser, F., Steiner, L.R. and Bernardin, A.M. (2012) Recycling of Porcelain Tile Polishing Residue in Portland Cement. Environmental Science \& Technology, 21, 2368-2374. http://dx.doi.org/10.1021/es203118w

[18] Phillips, R.W. (1991) Skinner's Science of Dental Materials, Chapter 8 Elastic Impression Materials: Alginate. 9th Edition, W.B. Saunders, Philadelphia, 123-133.

[19] Matsuya, S. and Yamane, M. (1981) Decomposition of Gypsum Bonded Investments. Journal of Dental Research, 60, 1418-1423. http://dx.doi.org/10.1177/00220345810600080501

[20] Rodríguez, N., Alonso, M., Grasa, G. and Abanades, J.C. (2008) Process for Capturing $\mathrm{CO}_{2}$ Arising from the Calcination of the $\mathrm{CaCO}_{3}$ Used in Cement Manufacture. Environmental Science \& Technology, 42, 6980-6984. http://dx.doi.org/10.1021/es800507c

[21] Reisbick, M.H. and Brantley, W.A. (1995) Mechanical Property and Microstructural Variations for Recast Low-Gold Alloy. Journal of Prosthodontics, 8, 346-350.

[22] Isaac, L., Joseph, M., Bhat, S. and Shetty, P. (2000) Stress Variations in Recast Ni-Cr alloy-A Finite Element Analysis. Indian Journal of Dental Research, 11, 27-32.

[23] Yilmaz, B., Ozcelik, T.B., Johnston, W.M., Kurtulmus-Yilmaz, S. and Company, A.M. (2012) Effect of Alloy Recasting on the Color of Opaque Porcelain Applied on Different Dental Alloy Systems. The Journal of Prosthetic Dentistry, 108, 362-369. http://dx.doi.org/10.1016/S0022-3913(12)60193-0

[24] Ibrahim, R.M., Seniour, S.H. and Sheehab, G.I. (1995) Recycling of Calcium Sulphatedihydrate. Egyptian Dental Journal, 41, 1253-1256. 
Scientific Research Publishing (SCIRP) is one of the largest Open Access journal publishers. It is currently publishing more than 200 open access, online, peer-reviewed journals covering a wide range of academic disciplines. SCIRP serves the worldwide academic communities and contributes to the progress and application of science with its publication.

Other selected journals from SCIRP are listed as below. Submit your manuscript to us via either submit@scirp.org or Online Submission Portal.
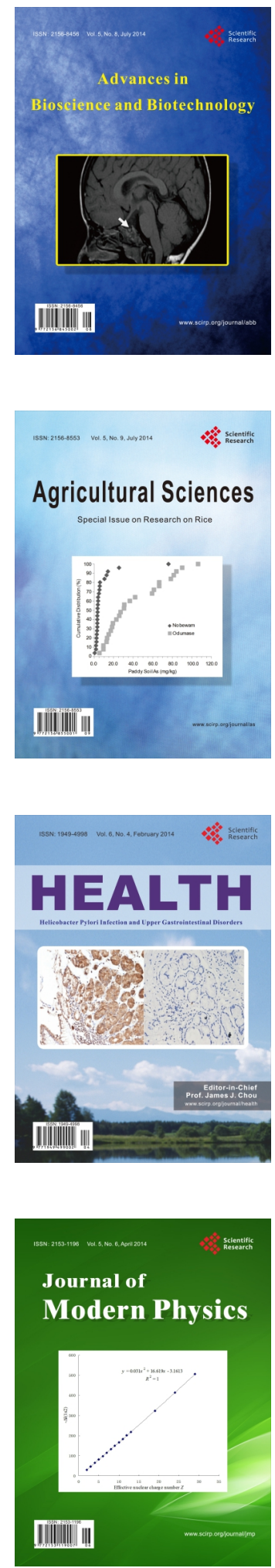
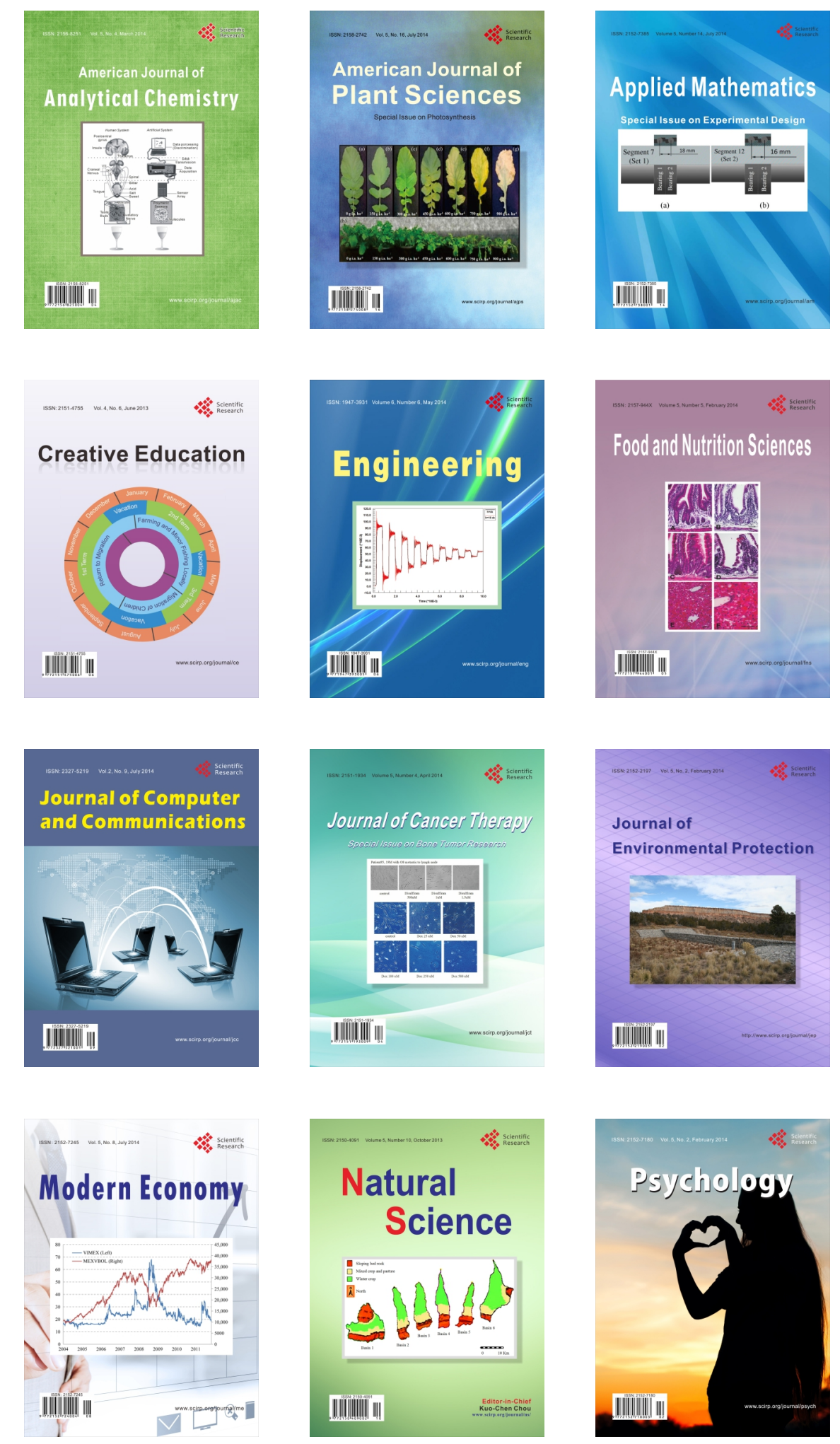